\title{
IMMIGRATION POLICIES IN HISTORICAL PERSPECTIVE: THE CASES OF FRANCE, THE FORMER WEST GERMANY, AND THE UNITED STATES*
}

\author{
Por \\ Felipe Cuamea Velázquez**
}

\begin{abstract}
RESUMEN
En este trabajo se analizan comparativamente diversas políticas de atracción y rechazo de trabajadores migratorios, así como las estrategias aplicadas en estas naciones para controlar los flujos de inmigrantes ilegales. En particular, se aborda la aplicación de sanciones económicas a empleadores que contratan a inmigrantes indocumentados, como estrategia para desincentivar tanto a empleadores como a indocumentados, esperando que para éstos sea muy difícil encontrar empleo. Se analizan también los limitados resultados de las sanciones económicas para controlar la inmigración indocumentada.
\end{abstract}

\begin{abstract}
In this work the author explores and compares both immigration policies devised to attract foreign labor when needed in the receiving nation, as well as policies aiming at curbing illegal immigration when this labor force is no longer wanted in the host nation. The main focus is on policies that impose economic sanctions on employers who knowingly hire illegal immigrants. Economic sanctions are intended to deter employers from hiring unauthorized immigrants, as well as to deter illegal immigrantion by making it more difficult for immigrants to land a job in the host nation. The limited and controversial success of these sanctions will be discussed as well.
\end{abstract}

\section{INTRODUCTION}

Most approaches to the study of international migration assert that the origin of international migration rests on economic imbalances, along with social and cultural factors, while disregarding other factors, such as states' immigration policies. International relations, foreign policies, ideologies, domestic policies, and interest groups very often shape the origins, timing,

\footnotetext{
* This article was accepted in May of 1996 to be publicated in Estudios Fronterizos.
}

**Researcher of the School of Economics, UABC-Tijuana. 
volume, and composition of international migration flows. This work addresses how France, the former West Germany, and the United States ${ }^{1}$ have shaped their immigration policies, how different political settings have had an impact on such policies, and whether or not the imposition of economic sanctions on employers has had the expected result of curbing illegal immigration.

\section{IMMIGRATION POLICIES IN WESTERN EUROPE}

Most West European countries attracted temporary foreign labor migration by means of guest-workers programs derived from bilateral labor agreements. The administration of foreign workers in the post-World War II era had three main strategies: first, and the more generalized alternative, was that receiving governments organized recruitment procedures in collaboration with authorities from the sending-nation government. Second, the sending nation was allowed to select and transport a quota of workers, who were then granted work and residency rights upon finding a job at their destination. The third option permitted host-nation employers to recruit foreign workers directly (Miller and Martin, 1982:53-61). ${ }^{2}$ Although guest-workers were supposed to return to their countries when they were no longer needed, significant numbers of migrants settled in host nations, an outcome not expected nor encouraged by some host governments, such as Germany.

In order to assess the impact of immigration policies on international migration flows in different European host nations, the cases of France and Germany will be examined.

\section{Immigration Policy in France}

After World War I, France strongly encouraged the immigration of foreign workers, particularly of young males, who were employed to reconstruct housing and industry damaged during the war. From 1919 to 1921, France established and maintained a system of rotational immigration from China

1 In the case of the United States, I will not make reference to the Immigration Reform and Control Act of 1986 (RCA), which imposed economic sanctions on employers who knowingly hire illegal aliens, as one of the centerpieces of the policy. Rather, in this work the author addresses the historical antecedents that finally led to the implementation of IRCA.

Although these are the most generalized procedures, particular practices varied from one country to another. For example, Algeria prohibited foreign governments from recruiting directly in its territory, even in cases when bilateral agreements were in effect. Algerian authorities were responsible for the selection, orientation, and departure of workers. (Miller and Martin, 1982:54). 
and Vietnam. However, few immigrants responded, compared with the government's expectations, and only a small population of immigrants resulted from that open policy (Verbunt, 1985:127). The economic growth that France experienced from 1922 to 1931 demanded a labor force, and as an alternative, the government created a legal framework regarding immigration. This policy had two objectives: first, to promote the importation of foreign labor, and second, to control recruitment, which had been organized and undertaken directly by employers without government interference. Consequently, the pro-immigration policy was so successful that France's immigrant population increased from almost 1.5 million in 1921 to 2.7 million by 1931 (Verbunt, 1985: table 5.1).

A period of economic crisis during the 1930's, widespread unemployed, and a very slow recovery led the French government to reverse its immigration policy. Foreign workers were strongly encouraged to leave, as a strategy to protect the labor market and to provide employment to nationals. Nevertheless, very few migrants returned to their countries of origin. The vast majority decided to stay, and applied for naturalization: from 1931 to 1939 , approximately 30,000 foreign workers were naturalized annually (Verbunt, 1985: table 5.1).

\section{The Post-World War II Period}

After World War II, France again encouraged foreign labor to immigrate, as it was necessary to meet the needs of the reconstruction period. During the period of 1945 to 1955 , the French government planned an immigration policy controlled by the state, which gave preference to Italian migrants because they were considered as "assimilable". In 1954, the Nationality Act was enacted to increase naturalizations, and the government created the National Immigration Office (NIO) as the sole organization responsible for the organization and recruitment of foreign workers. Stephen Castles argues, however, that the apparently great level of organization of the NIO as foreign labor recruiter may be quite misleading. According to data from the $\mathrm{NIO}$, the proportion of workers entering France illegally increased from 26 percent in 1948 , to 82 percent in 1968 (Castles, 1986:763). Castles continues by saying that controlling foreign workers became more difficult as competition for foreign labor increased in Western Europe as a consequence of the economic "boom" period. The NIO was incapable of meeting employers' needs, and "spontaneous" migration flows started to develop from Spain, Portugal and Yugoslavia (Castles, 1986:764). Illegal workers met employers' needs. These illegal workers were a very flexible labor force that could be 
forced to accept poor wages and working conditions. Since employers needed the workers rapidly and in large numbers, both employers and foreign workers neglected the official channels of worker recruitment. Mark J. Miller and Philip Martin, and Gilles Verbunt view the inefficiency of the governmental recruitment process as a key factor in leading employers and prospective workers to elude formal procedures. As the first step of the official process, the employer requested foreign workers, and paid a fee to the government. The second step was that labor ministry officials had to concur that no nationals could in fact be found for the job, and that recruitment of foreign workers would not depress wages or working conditions. As a third step, the labor ministry had to send a notice of an unfilled job to the European Economic Community's labor exchange office; if the job remained unfilled after two weeks of notification, the notice was sent to non-EEC countries. According to Miller and Martin, employers' requests for non-EEC workers were generally approved for transmittal to govemment-run recruitment offices abroad after a month's delay. The slowness of the official recruitment process, conclude the authors, "encouraged French employers to hire illegal aliens on the spot..." (Miller and Martin, 1982:54).

\section{The Immigration Ban}

The practice of foreign-worker recruitment was in effect in France until 1973, the year of the European Immigration Ban. That same year, the Council of Europe Recommendation 712 of its Consultative Assembly, section (d) 9 supported the

Intensification of investigations concerning the employment of illegal immigrants, with fines or prison sentences for offending employers and persons responsible for organizing the clandestine entry of such persons into immigration countries (Miller and Martin, 1982:176).

One year later, Resolution (74)14 of the Council of Europe's Committee of Ministers (May 1974). "Invited Governments to...take care to prevent by the appropriate means the introduction of clandestine foreign manpower and its exploitation, in particular by taking effective sanctions against those responsible for these abuses" (Miller and Martin, 1982).

Prospective migrants in sending countries were also encouraged to engage in illegal migration, because the officials in the sending country operated with lists of "priority" candidates. The large waiting lists fostered corruption, because desperate candidates would offer or would be asked to pay, a bribe in order to receive priority. These migrants would enter 
illegally into their country of destination, would seek a job, and afterwards could become legal workers.

If the middle-to-late 1950's was a period of flexible migration control that fostered illegal entry of foreign workers, the 1963-1973 period was characterized by what Verbunt calls a laissez-faire policy, because only 10 to 30 percent of immigration was controlled (Verbunt, 1985:136). This relaxed government attitude resulted in the phenomenon of "immigration from within", because illegal migrants were legalized under the auspices of recruitment programs, once they had secured a job. By the late 1960 's, between 70 and 80 percent of foreign workers were legalized "from within" every year (Verbunt, 1985; Moulier and Tapinos, 1979:131-132).

The lack of state intervention in controlling immigration and the open flexibility for foreign workers began to draw sharp criticism by the end of the 1960's. Protests against the working and housing conditions of foreign workers, and the beginning of increases in unemployment among French workers, fueled popular sentiment calling for a new immigration policy.

In 1974, Giscard d'Estaing introduced several changes concerning immigration, including the creation of the Ministry of State for Immigration Workers, which had as its main goals the prevention of new immigration - even family immigration - and the improvement of social conditions for the established immigrant population. In spite of expulsions of illegal immigrants during the 1970's, the immigration ban, and the anti-immigrant movement fueled by right-wing groups such as Le Pen's National Front, the influx of both legal and illegal immigrants continued. By the late 1970's, immigration policy had become a political and electoral issue, capitalized upon by the rightist National Front, which emerged as a significant political force in 1980 (Messina, 1990:33-35). By 1980, the estimate of illegal aliens in France was between 300,000 and 500,000, which represented between 5 and 15 percent of the total legal resident alien population in the country (Miller and Martin, 1982:59).

France undertook several attempts to encourage return migration. First, in 1974 the government offered free transportation for needy migrants willing to retum to their home countries.

Second, in 1977 foreigners were offered free transportation plus 10,000 francs, if they would return to their countries. Although these attempts were criticized as a measure to "get rid of unemployed" people, the strategy continued until the early 1980 's. Almost 100,000 foreigners $(60,000$ of them, workers) took advantage of the 10,000-francs offer, and left (Verbunt, 1985:144; Lebon, 1983:154, 160). By 1980 the government had approved almost 45,000 applications, which covered approximately 
85,000 foreign nationals, including workers and their dependents. Third, France offered occupational training for those willing to leave.

France enacted employer sanctions in order to reduce the influx of illegal immigrants; one change introduced with the new legislation, was that employers were made responsible for assuring the eligibility of aliens to work legally. They were required to keep records of the employee's address, work and residence permits, etc. In 1982, a new law was enacted to allow the NIO to confiscate employers' tools and equipment if they hired illegal aliens. However, in 1985 French officials reported that controlling illegal aliens was still a great problem, and they estimated that illegal immigration had increased since 1981, despite employer sanctions. Government officials argued that the reason for the increase was that it was cheaper for employers to hire illegal immigrants for short-term labor needs; an additional factor was the increasing difficulty for legal aliens to obtain or renew their work permits, which forced them to seek work illegally (U.S. General Accounting Office, 1985:10).

\section{German Immigration Policy}

German was an emigration country until the 1880 's, but economic expansion in the late nineteenth century brought her immigration flows from Poland and Austria to provide the manpower necessary to compensate for gaps in the domestic labor force. Germany began to put in practice several immigration strategies which were strongly determined by the economic and political conditions of those years. Late nineteenth century Germany relied on foreign workers as a means to end labor shortages in agriculture, caused mainly by the high emigration rate of peasants to the cities, and by a change in production to more profitable, but labor-intensive agricultural production. As a consequence, the Prussian government lifted the ban on Poles in 1890 , but only for a period of three years.

Although the border was opened to Polish workers, they were required to leave Germany every year during a waiting period from November to April, as a strategy to prevent them from seeking permanent residence. Furthermore, Poles' jobs were tied to agriculture, and they were not allowed to move from agricultural areas in the east to the industrial cities of the west (Esser and Korte, 1985:167).

By the end of the century, because of the necessity of foreign workers, Poles were given the status of seasonal workers. Their access to other agricultural areas was made easier, immigration restrictions were relaxed, and political opposition to foreign immigration was temporarily appeased. 
By 1908, 308,000 foreign agricultural workers were employed in Prussia, and 80 percent of them were Polish workers (Esser and Korte, 1985:167).

The First World War brought a dramatic reversal regarding immigration flexibility toward Polish workers. Poles were forbidden to return home, and at the outbreak of the war, their passports were destroyed to prevent them from leaving the country. Because of further increases in labor shortages during the war, however, Germany lifted the prohibition that prevented Polish workers from working in industrial areas, and recruited increasing numbers of Poles. Labor demands were controlled by the German Labor Office, which had the monopoly of "recruiting" Polish workers from the occupied areas in the east. As soon as Polish workers crossed the German border, they were not allowed to return home; almost 700,000 Poles were "recruited" in this manner during the war, along with Belgians and Hungarians who were also forced to work for the German war economy (Esser and Korte, 1985:168).

During the 1930's the Nazi war economy put in to practice German strategies from the First World War. The slow economic recovery beginning in 1934 brought a rise in the number of foreign workers, mainly due to the need for them in agricultural and industrial jobs. From 1934 to 1938 the number of foreign workers rose from 100,000 to almost 400,000 . When the Reich realized that Germany was not very attractive to foreign workers because of their prior experiences, and that voluntary recruitment had not provided sufficient manpower to meet military production, the Nazis devised a new policy. The Aliens Decree of 1938 prohibited foreign workers, particularly those from enemy countries, from leaving Germany. Furthermore, the Reich gave police authorities total control over foreign workers' rights and liberties. By 1945, almost eight million foreigners worked for the German Reich; approximately six million were civilians forced laborers, and the rest were prisoners of war (Esser and Korte, 1985: 169).

\section{The Post-World War II Immigration}

Germany was one of the Westem European nations that had a late entry into the post-war labor-import market. Unlike other European nations, its reconstruction began only after 1948 , and because of the large number of internal labor reserves, refugees and former forced workers who were prevented from leaving the country in 1938. Germans could not begin their reconstruction process until an international agreement concerning the economic and political future of Germany was reached among allied nations (Hollifield, 1992:48). In 1951 the government created the Federal 
Institute of Labor (FL), in which government officials, employers, and unions would each have one third of the votes in any decision regarding the importation of labor. According Esser, Korte, and Castles, this type of operation made the FIL the most organized and effective state-run control instrument in Western Europe until the reaching of the first binational labor agreement (Hollifield, 1992:170; Casles, 1986:769).

In the mid-1950's the FIL established an extensive system of recruitment offices in the Mediterranean countries. Germany's immigration policies, particularly the guest-worker program, made it clear that the nation did not encourage the long-term residency of workers, and that foreign workers were seen as a temporary solution to the nation's economic needs. Workers were expected to return to their countries when economic needs and labor shortages had become stable.

Germany's recruitment procedure was very similar to the one operated by France: the employer notified the nearest employment office of its labor needs, then the office determined whether German workers were available for the jobs. When no domestic labor force was available, the employment office sent its request to the Federal Labor Office, and from there it was sent to the recruiting office in the sending country (Mehrlander, 1983:150).

The declared "non-immigration" policy was not succeessful, and many guest-workers gradually began to settle in the country, thus contravening the intended purpose of the policy and the guest- worker program. In order to enter and remain in Germany, foreign workers needed both a residence and a labor permit. Work permits operated under strong restrictions, as instruments to exert control over foreign workers; most of the time permits were granted for specific periods and for certain specific jobs, very often tied to a specific employer and restricted to specific areas. Recruited Turkish workers, for instance, might receive a one-year labor permit for construction work with one German firm in the Rhur (Wilpert, 1992:178; Gurak and Caces, 1992:150-176). This type of contract was aimed at strict control of the foreign labor force, to restrict geographic and labor mobility, as well as to ensure that workers returned home when contracts had expired. One regulation, in effect until the early 1970's, stipulated that residency and work permits routinely had to be renewed annually, so that workers needed to contact the recruitment office every year in order to remain in the country. Once firms had trained their guest-workers during the first year on the job, FIL officials extended new labor and residence permits (Wilpert, 1982:178; Gurak and Caces, 1992:150-176; Mehrlander, 1983:150; Esser and Korte, 1985:184), thus contravening the spirit of the official principle guiding the guest-worker program which was intended to be as a worker-rotation program. Foreign workers were supposed to 
have to leave the country once their permits had expired, so that they could be replaced by a new wave of recruited migrants from the home country.

The great turnover in labor was the key factor that led German officials to extend work permits, and since foreign labor was still needed, officials of the FIL acted less restrictively, and even allowed family immigration by the late 1960's.

Although officially the Federal Institute of Labor had the monopoly of recruiting foreign labor, a proportion of foreign labor did not enter into the country under its control. For instance, evidence shows that about 82 percent of the labor demand for Turks between 1961 and 1976 was met directly by the official recruitment process. Other sources estimate that approximately one quarter of foreign labor, in Germany was recruited outside the FIL (Wilpert, 1992:179); Czarina Wilpert's estimations, based on FIL data, suggest that for the period from 1961 to 1971,68 percent of newly-registered Turks in Germany arrived under the auspices of the official recruitment process, and almost one-third of them arranged legal work on their own.

By early 1970 's, only two-fifths of Turkish workers entered Germany by FL procedures, which suggests that the remaining Turkish workers migrated on their own, or through personal connections and networks. According to Wilpert, one possible explanation for the non-officially channeled foreign workers rests in one of the provisions of the FL: German firms with over 500 employers were able to hire foreign workers directly (Wilpert, 1992:184). The firms typically identified and contacted prospective workers by using networks already established by their current Turkish workers, and then provided these prospective migrants with work permits. Another strategy used by German firms was to request and name specific individuals from the official waiting lists. Information they had received from Turkish workers in Germany; frequently, the names of individuals requested by employers were not in the official lists, and their names were included as recommended by employers (Wilpert, 1992:184). Ultimately, German firms took advantage of these non-official procedures, and enhanced migration networks of Turkish workers from specific regions in Turkey to certain areas in Germany.

\section{The Immigration Ban}

As a result of the oil embargo and the economic crises of the early 1970's, Germany stopped recruiting foreign workers in 1973. At that time the number of foreign workers (EEC and non-EEC workers) was 2.5 million. After the immigration ban, the number of foreign workers in Germany 
dropped to 2.1 million in $1974,1.9$ million in 1975 , and 1.8 million foreign workers in 1978. By 1987, however, the foreign population in Germany increased to a peak of 4.3 million, which represented approximately 7 percent of the total population (Esser and Korte, 1985:173).

Nevertheless, the official expectation was for a more significant reduction in the number of foreign workers in the country as a result of economic conditions. The government expected, that as during 1966-1967, when under economic recession the number of foreigners employed in the country those years dropped by 300,000 , a reduction in foreign workers would alleviate unemployment. However, the expected massive emigration of workers as a result of unemployment and economic recession did not occur.

One impact of the immigration ban of 1973 was that migrants did not leave because they feared they would not be allowed to return to Germany. The immigration ban also brought a change in the composition of foreigners by allowing family immigration. The German government shifted its immigration priorities towards a policy dealing with the fact of Iong-term residency by foreigners, and the social implications of that residency. As a means to provide an alternative to the social challenges of the settlement of foreigners, the government launched in 1973 a Program for the Employment of Immigrant Labor. The government realized that the first generation of "guest-workers" could no longer be considered as such because of their length of stay in the country, and that new strategies were needed to cope with foreigners who decided to stay.

In 1975, the Federal Chancellery formulated guidelines for immigration policy, demanding that priority be given to the social integration, education, and welfare over the economic aspects of immigration. At the same time, the Chancellery demanded the integration of immigrant families and the implementation of a plan to encourage return migration (Esser and Korte, 1985:174). ${ }^{3}$ These policies seemed to be based on the assumption that the economic attraction of Germany would not be a factor in the process of controlling undocumented immigration, as well as in the strategy to promote retum migration. Furthermore, these policies totally disregarded the influence of economic forces, as if the demand of

3 The essays edited by Kubat in his Politics of Retum discuss the impact of returned migrants in both their countries of origin and their host nations. To some extent, these essays provide partial evidence of the differentiated effects of return-migration policies implemented in Western Europe since the early 1970's. In host nations the expectations of success in with regard to return migration were not fulfilled. For example, when France attempted to "induce" Algerians to leave, the Spaniards and Portuguese seem to have benefitted the most, taking advantage of the "allowance" policy in late 1970's that provided money for those willing to return to their countries (Kubat, 1983). 
foreign labor had no role in the migration process, nor any influence on immigration policies. The implementation of these policies show the difficulty of reconciling contradictory policies: on the one hand, the promotion of family immigration, and on the other hand, the promotion of return migration. It was the contradictory character of these policies which in tum made their implementation extremely difficult.

\section{Implementation of Immigration Policy}

In Germany, the Federal Government (Ministry of Labor and Ministry of the Interior), the employers, and the unions have determined immigration policy. The guidelines for immigration are drawn up in committees where the federation of trade unions, the employers' federations, and the Federal government exert the greatest influence. Remarkably, the legislative branch remains largely excluded from involvement in immigration issues. The immigration authorities in charge of the control of foreigners are part of the federal government, and are established in each region, while in Berlin the police department is responsible to the immigration office. In Northrhine-Westfalia enforcement of immigration policies rests on the municipal authorities (Esser and Korte, 1985:203),

Despite employer sanctions, the control of illegal aliens in Germany is still a great problem. Prior to 1982 , when the government shifted its strategy to border interdiction as a means to control illegal immigration, German authorities focused on employers and alien smugglers. In the mid-1970's German employers who knowingly hired illegal workers or kept foreign workers whose permits had expired, were subject to three to five years in jail and/or fines of up to 50,000 DM(\$20,000). In 1976 alone, almost 10,000 German employers were fined for employing illegal workers (U.S. General Accounting Office, 1985:8). In 1982, German officials reported that despite employer sanction laws, the hiring of illegal workers was still a significant problem. According to officials, the reason the sanctions failed was that when employers were caught, they successfully appealed the administrative fines imposed.

Despite the existence of a German national system of identification for immigrants, the system has not been able to control migrant workers whose residence or work permits have expired. Migrants whose permits have expired fear the risk of not being able to renew their visas, and many opt to remain underground. The identification system theoretically enables authorities to keep track of migrants, since permits are granted on regional and sectoral bases, and each is valid only for a specific city and job. 
However, the system is far from successful in controlling the migrant population in the country.

Because of Germany's problems with the internal control of migrants, in 1982 the government passed a new law that was intended to correct some of the shortcomings of existing laws. Five new provisions were introduced: first, the new legislation increased penalties; second, it made employers responsible for determining whether workers hired through leasing firms were legal aliens; third, it allowed greater cooperation among governmental agencies that had information on illegal employment; fourth, it prohibited the temporary employment of manual laborers in the construction industry; and fifth, the law made it illegal for any individual or any transportation company to bring illegal aliens into the country (U.S. General Accounting Office, 1985:9).

In April, 1985, a new piece of legislation was enacted that defined new punishable offenses for employers and subcontractors of illegal aliens, "wherever such employment would have a detrimental impact on the employment market" (U.S. Gemeral Accounting Office, 1985. Emphasis added ). It is now the responsibility of labor offices for prosecuting illegal employment. This provision, similar to ones in the United States, made enforcement extremely difficult. First, authorities have to prove that in fact the employment of illegal immigrants is having a detrimental effect on the labor market; second, the provision implies that only when employment of illegal immigrants has a negative effect should employers be penalized. Therefore, one may conclude that insofar as no negative impact on the labor market is found, illegal immigrants may be legally hired. Even in cases when employers might be found as responsible of hiring illegal immigrants, the law does not define any mechanism nor criteria for how to determine the existence of detrimental effect on the labor market as a consequence of illegal immigrantion.

The law also created 30 special offices attached to local labor offices. These special offices would prosecute major infractions "in certain industries and/or regions" defined as being in need of extensive investigation. This selective enforcement by regions and sectors, as well as the ostensible focus on "major infractions", suggests a discretionary implementation of the policy, which seeks compliance by a sort of "demonstration effect" or by setting an example, rather than by aiming at a full enforcement of policies. Although the number of fines increased from 3,179 fines in 1982, to 3,471 in 1983, and to 4,008 fines on employers of illegal aliens in 1984, employers seem to continue hiring illegal aliens, particularly in small and medium-sized construction firms, in bars, and in the hotel and restaurant industry (U.S. General Accounting Office, 1985). 
The implementation of policies such as the guest-workers programs often result in unintended effects. Policymakers wanted to create a temporary labor force, relying on short term importation of that labor force. Strict legal regulations and recruitment controls that accompanied the implementation of the guest-worker programs, seem to have conflicted with employers' needs in terms of the efficiency of recruitment. Employers found more efficiency by keeping for more than one year foreign workers already trained on the job, instead of letting those workers go home and be replaced by new workers every year, just as the government's guidelines indicated. A successful policy meant that foreign workers had to leave after one year, and then they would be replaced by new workers, who would need to be re-trained. Apparently, the strong effort made by government officials in charge of implementing policies and controlling foreign workers encouraged employers and migrants to seek ways around the formal process in order to meet their respective needs.

Despite the intended purpose of seeking out temporary migration to meet short-run economic needs, and explicitly opposing permanent migration, host nations have experienced a gradual process of migrant settlement.

\section{THE UNITED STATES IMMIGRATION POLICY AND MEXICAN ILLEGAL IMMIGRATION}

Mexican migration towards the United States is a process shaped by a variety of factors, such as the historical presence of large numbers of Mexicans in what is now the American Southwest; the social, and cultural ties that have persisted and enhanced between the Mexican population and those of Mexican descent in the U.S. who predate the U.S.- Mexican War period, as well as the economic, social and political conditions in both countries. One factor that is also fundamental to the understanding of the main features of Mexican migration to the United States is the influence of different U.S. immigration policies.

In the early nineteenth century, the United States encouraged immigration. European peasants came, escaping famines and scarcity of land in their homelands. During the second half of the century, increasing numbers of Europeans displaced by the Industrial Revolution arrived in the promised land. As early as 1840 , Chinese workers were recruited to provide labor in Hawaii and California, and after the American Civil War, the expansion of the frontier in the territories of the Southwest fueled the need for labor in the mobile frontier. The first significant federal immigration law in the last century, passed in 1864, titled "An Act to 
Encourage Immigration", was a response to industrialists' complaints of a reduced labor supply as a consequence of both the Civil War and a decrease in immigration, which in turn led to a rise in wages ${ }^{4}$ (Hutchinson, 1981:49).

The open-door policy brought about a million migrants every year into the United States as the end of the nineteenth century approached. However, what employers considered as a plausible policy, since the large pool of workers available depressed wages, produced a negative reaction from domestic workers and the labor movement. The labor movement began to organize nationally and called for a restriction on immigration. Its first victory resulted in the 1882 Chinese immigration exclusion (Hutchinson, 1981:80-81; Handlin, 1990:15-25), which still did not prevent employers from hiring Chinese workers, particularly in the Mid-and-Northwest railroad industry and in the agricultural sector of the Southwest. Gradually the number of Chinese workers in the West lessened, as they were being recruited in smaller number than in the past. The AntiAlien Contract Law of 1885 banned the importation of contract workers, as a means of appeasing growing discontent within the labor movement. But as Kitty Calavita observes, "Congress enacted a measure that responded politically to the demands of the organized labor, but did not interrupt the immigrant stream" (Calavita, 1992:5). This type of legislation shows an intention to solve the problem of immigration, although it lacks the effective means to accomplish that goal.

As the agricultural and railroad expansion of the 1880's reached its peak, U.S. employers needed a new source of labor. By the end of the century they had begun to recruit Mexican agricultural and railroad workers as an alternative to Chinese migrants, because Mexicans were closer and more readily available. These Mexican workers were first employed in the construction of the Mexican railroad system launched by the Porfirian regime, as one of the centerpieces of Mexican modernization.

Beginning with the 1880 's, the Mexican government engaged in the largest railroad expansion in the history of the country, as part of its economic modernization project. Large extensions of land and mines were

4 President Lincoln's message to the Congress in 1863 recommended the encouragement of immigration by saying:

I again submit to your consideration the expediency of establishing a system for the encouragement of immigration. Although this source of national wealth and strength is again flowing with greater freedom than for several years before the insurrection occurred, there is still a great deficiency of laborers in every field of industry, especially in agriculture and in our mines...,

quoted in Hưtchinson (1981:48). 
concessioned or sold to American and British investors in Mexico's Northwest and other parts of the country. Railroad expansion brought the displacement of thousands of peasants, because Indian property was illegally taken to build the new railroad system, and violent confrontations between the indigenous population and the government forces often originated from land disputes. ${ }^{5}$ According to Massey et al., Mexican emigration to the United States was influenced by the economic expansion in the U.S. Southwest and by social and economic conditions prevailing in Mexico. The Porfirian economic development also created conditions favorable to Mexican migration, particularly towards the turn of the century, when in addition to the enclosure of communal lands, falling wages in agriculture, a shift to capital-intensive production methods, and decreasing opportunities for urban employment in a nation predominantly rural, resulted in a mass of peasants without ties to the land (Massey, Alarcon, Durand and Gonzalez, 1987:40). The growing need for manpower in the Southwest and the displaced peasants in Mexico were connected, according to Cardoso, by the railroad expansion on both sides of the border (Cardoso, 1980; Fernandez, 1977:82-88). The first railroad reached western Mexico in 1885, and the United States and Mexico were connected by railroad in 1884 . The Porfirian railroad program's northward was critical, and further construction was strongly supported by the regime. This was because Mexico's economic growth was oriented not to internal development and employment, but to extraction of raw materials and exports.

By the end of the nineteenth century U.S. railroad companies, especially the Southern Pacific, Atchison, Topeka, and the Santa Fe began to recruit Mexican railroad workers. These workers had been employed by Mexican companies, and many of them were laid off when railroad construction ended in the Mexican border states. By 1900, the U.S. Census reported few more than 100,000 Mexican-born persons in the United States. That same year, the proportion of Mexican workers employed in the railroad industry in New Mexico, Arizona, and Texas represented 15.1, 35.5, and 14.7 percent, respectively, of the total labor force employed in railroads in those states (Driscoll, 1985:10). In September, 1907, for example, only 30 of the $\mathbf{4 0 0}$ Mexican border railroad workers whose contracts with the Mexican government had expired returned to their

5 The modernization process launched by Diaz generated turbulent violence and abuse against Indians. See John Coatsworth, "Railroad, Landholding, and Agrarian Protest in the Early Porfiriato" (1974:48-71), De Vos' (1974:76-113) analysis provides a detailed account of violent confrontations between Indians and government forces derived directly from land disputes in areas of railroad construction. 
places of origin in Central Mexico. Most of those who did not return were contracted by U.S. companies. By 1940, the percentage of Mexican workers in these states was estimated at 32,81 , and 48 percent respectively. This shows to some extent the results of labor recruitment since the late nineteenth century (Driscoll, 1985:11).

\section{The Second Bracero Program: Wartime Recruitment and Binational Cooperation}

Beginning in early 1940, food-crop growers in California, Texas, and Arizona reported labor shortages, and in 1941 they requested permission from the United States Immigration Service to import Mexican Workers. Their demands were denied, although a year later with the United States' entry into the war, the situation changed drastically. In 1942 the Immigration and Naturalization Service (INS) formed a committee together with several federal agencies, to analyze the possibility of initiating a labor importation program. After a period of informal negotiations with the Mexican government, in April, 1942, the two countries signed the bilateral agreement known as the Bracero Program, in order to solve the U.S. problem of wartime labor shortages (Driscoll, 1985:13). Seven months later, in 1943, when almost 60,000 braceros were in the U.S. under the auspices of the agreement, Congress enacted Public Law 45 endorsing the bracero program ${ }^{6}$ (Keely, 1990:5). In August 1943, the two governments signed an additional non-agricultural program for Mexican railroad workers. This program lasted until August, 1945. By April, 1944, almost 40,000 Mexicans were employed on 24 railroads, and the peak level of contracted workers for that year reached more than 80,000 workers (Galarza, 1964:54; Driscoll, 1985:13-21; Gamboa, 1990; Morales, 1982:114-118).

The agricultural workers agreement establised that braceros were not to be paid less than domestic workers doing similar work, and that piece rates would be calculated to allow the average bracero to earn at least the minimum hourly wage. Braceros would be allowed to elect representatives to discuss complaints with their employers, except those involving contract conditions which were non-negotiable. The Mexican govemment also prohibited Texas employers from hiring braceros, arguing a history of discrimination and abuse of Mexican workers in that state.

6 His estimations are based on Cornelius' data. (Keely, 1990).

7 The state of Texas appointed the "Good Neighbor Commission", which strongly lobbied for the inclusion of Texas as one of the areas that could benefit from contract workers. However, 
The conditions upon which the Mexican government was willing to consider the agreement were the following:

1. Recruitment would be based on a written labor contract.

2. The administration of the program would be carried out by both governments, and contract compliance would be guaranteed by the same.

3. Recruitment would be based on need: i.e. Mexican workers would not displace domestic labor nor depress their wages.

4. Employers would pay transportation and subsistence costs to and from the recruitment center and the work site.

5. Migrants would not be encouraged to remain permanently in the United States.

6. Racial discrimination of the type in which Mexicans were turned away from "white" restaurants and public facilities or sorted by color on buses would be prohibited (García y Griego, 1983a:9).

One of the goals of the Mexican government was to have a regulatory instrument between the two governments, in order to protect the rights of Mexican migrants and to prevent the U.S. authorities' unilateral expulsion of workers, as had ocurred in previous decades. Nonetheless, one of the provisions of PL 45 authorized the INS Commissioner to admit contract workers on his own terms, which meant a unilateral reversal in the terms of the agreement. The provision was intended to respond to possible growers' complaints, in case they were affected by the slowness of the official recruitment procedure as processed through the Mexican government. ${ }^{8}$ Since the recruitment centers were established in Mexico City, Guadalajara, and Irapuato in Central Mexico, growers had insisted since the beginning of the agreement on recruitment centers at the border not only as a means of expediency, but also as a way of reduce transportation costs from Central Mexico. As an alternative way to reduce the time-consuming process of recruitment and transportation costs, the INS Commissioner decided to allow employers to select their own workers

the efforts of the commission were fruitless; the exclusion of the state was not lifted, at least not by Mexican authorities. The exclusion resulted in further conflicts. See García y Griego, "The Importation of Mexican Contract Labor to the United States, 1942-1964. Antecedents, Operation, and Legacy" (1983b: 60). (This is an expanded and revised version of García y Griego's work published in 1981, and which is cited below).

8 The specific aspects of the operation of the program, its administrative shortcomings in the recruitment process, and the problems of inter-agency and inter-governmental cooperation are discussed by Ernesto Galarza in his Merchants of Labor (1964). Initially, recruitment took place only in Mexico City, but the massive influx of prospective migrants made it difficult for authorities to handle the situation efficiently with only one recruitment center. 
at the border, opening the program to Texas growers who were excluded by the international agreement. Because of extensive labor shortages in Texas, immigration officers were instructed "to defer the apprehension of Mexicans employed on Texas farms" as a way to meet growers' need of workers (Calavita, 1992:23).

The decision of the Immigration Commissioner fueled strong protests from the Mexican authorities, who demanded that the U.S. should take a stronger stand against illegal immigration. The U.S. government, on the other hand, charged that Mexican authorities were taking advantage of the Bracero Program to induce thousands of workers to migrate to the U.S. on their own inititative, without following the procedures established by both governments. Consequently, both governments agreed that it was necessary to protect the border, and make attempts to curb illegal crossings. However, most of expelled illegals were returned through the Mexican ports of Tijuana and Mexicali, which were practically isolated from the rest of Mexico, and that condition complicated deportees' return to their origins in Central and West Mexico. As a result, deported workers remained in Tijuana and Mexicali, waiting to make a new attempt to cross illegally. Mexican authorities opted for closing these border ports to the return of deported illegal migrants, trying to force U.S. authorities to deport illegal aliens through border ports where workers had more access to the interior of Mexico (García y Griego, 1983b:62).

In October, 1945, members of Congress from states employing braceros, the Secretary of Agriculture, and growers' representatives, urged an extension of the bracero program, arguing that domestic workers were not willing to take those jobs held by Mexicans. However, the war having ended, the Department of State notified Mexico on November 15, 1946, of its desire to end the agreement within 90 days (Galarza, 1964:48-49). Employers continued to demand bracero workers, and in April, 1947, Public Law 40 was passed, extending the program until December 31 of that year. However, negotiations with Mexico were resumed in 1948, and the State Department signed a new agreement with Mexico, extending the labor contract until 1952 (García y Griego, 1992:92).

\footnotetext{
9 Craig argues that it seemed contradictory for the Mexican government to oppose illegal immigration to the U.S., given that the flows, both legal and illegal, had great benefits for Mexico in terms of remittances and in reduction of unemployment in rural areas. Craig's argument is that such opposition stems from political embarrassment to the government, due to the magnitude of the exodus, and also because the government believed that the continuation of legal immigration and strong law enforcement could reduce illegal immigration. See Richard B. Craig. The Bracero Program. Interest Groups and Foreign Policy. (1971:58-60).
} 
The practice of employers' directly hiring foreign workers continued, and due to increases in farmers' labor demands, the INS office in El Paso admitted almost 1,500 braceros in only one day in 1948. Between October 13 and October 18 the INS' chief patrol inspector at El Paso stated that 6,000 illegals were arrested, after which they were paroled to Texas growers. ${ }^{10}$ Although the process was stopped several weeks later, it showed the discretionary operation of the program, also how banned employers and the INS could circumvent the law.

Calavita describes the contradictory INS situation in the following terms: "faced with the economic utility of illegal aliens on the one hand, and its bureaucratic mandate to halt the flow on the other, the INS found itself in a catch-22 that almost perfectly mirrored the underlying structural contradictions." ${ }^{11}$ (Calavita, 1992:38).

Because only 31,331 braceros had been contracted by the summer of 1947, the INs legalized 55,000 undocumented aliens in Texas, circumventing the law because Texas was excluded by the agreement, and the practice went on for several years (Keely, 1990:52). The normal practice was to take undocumented workers to the Mexican border, then allow them to come back, legalized by the INS, and sent as legal braceros to the fields. This is evidence that the increase in illegal migration was not only a by product of the bracero program, but was also a result of INS practices that encouraged illegal immigration by "drying the wetback". During the 1940's it was normal practice of the INS, as recognized by their officials, not to apprehend illegal workers, because it could harm the harvesting of the crops.

The increasing number of undocumented migrants after the bracero program was signed, and the contradictions that emerged from the provisions of the agreement and the practices of the INS led to a de facto two-fold policy. First, between 1947 and 1951 the U.S. practiced mass legalization of undocumented workers, and then, between 1954 and 1955

\footnotetext{
${ }^{10}$ Since 1942, the Mexican government had excluded Texas from receiving workers, but after U.S. Government negotiations on behalf of Texas growers, they were included in the agreement. The 1948 border incident derived from a demand made by the Mexican government that cotton picking wages should be raised from $\$ 2.50$ per hundred pounds to \$3.00. Texas Growers bad fixed that wage a year earlier, and they argued that they had not been challenged by the U.S. government on that matter. Therefore, the Mexican demand was considered as an intrusion in U.S. internal affairs. These events led the U.S. Immigration Commissioner to open the border to legal braceros and to "legalizar" apprehended braceros in order to sead them to the Texas fields. (Galarza, 1964:49; García y Griego, 1983a:64).

II Calavita observes that such contradictions resulted from congressional pressure on the INS by means of the appropriation of insufficient funds. The DNS District Director at El Paso testified before the President's Migration Commission: "All we need is a go-ahead signal and we can enforce the law 90 to 95 percent". Quoted by Calavita (1992: 37).
} 
they commenced simultaneous practices of mass expulsion and massive legalization. The first period provided legal availability of undocumented labor due to its increasing demand; the second period featured the massive expulsion of undocumented workers, or "Operation Wetback", in which thousands of illegal workers were taken to the Mexican side of the border and thereafter granted legalization. The increase of undocumented migration did not slow; it was simply legalized to provide a flexible and available labor force.

Another border incident, known as the second "Bl Paso Incident" took place in 1948, when the local INS office at El Paso unilaterally opened the border to braceros, violating the agreement again. The Mexican government opposed that decision, and abrogated the agreement. The Mexican government attempted to stop braceros from crossing the borders by displaying the police and armed forces very visible in several border cities. However, workers continued to cross, and after the State Department apologized, negotiations were resumed to extend the agreement, which lasted until 1964.

\section{The McCarran-Walter Act of 1952, and the Case of Employers Sanctions}

When the United States entered into the Korean War, the Mexican government strengthened its position in the bracero negotiations. The Mexican government requested U.S. congressional legislation to create a formal framework for the bracero program, and to penalize employers of undocumented Mexican workers. In 1951, Senators Douglas, Morse, and Humphrey attempted to amend Section 984 (which later became Public Law 78, or the McCarran-Walter Act), as a response to Mexican demands that the U.S. reduce illegal immigration, and to the recommendations of the President's Commission on Migratory Labor (Craig, 1971:72-74). Senator Douglas's amendment provided:

Any person who shall employ any Mexican alien...when sucb person knows or has reasonable grounds to believe or suspect or by reasonable inquiry could have ascertained that such an alien is unlawfully within the United States...and shall fail to report such information promptly to an immigration officer, shall be guilty of a felony... (Calavita, 1992:67; Hutchinson, 1981:302-303).

Although the amendment passed the Senate by a narrow margin, it was deleted from the bill by the Chairman of the Conference Committee (Democrat Allen Ellender of Louisiana, who, incidentally, represented 
agricultural interests). As pressure from Mexico continued because the final version of S.984 did not include any penalty for employers of undocumented workers, conditions were not favorable for the re-negotiation of the bracero agreement. Douglas's amendment was replaced by a bill introduced by Senator Kilgore, that made it illegal only "to harbor, transport, and conceal" illegal aliens. The Texas delegation introduced an additional amendment, known as the Texas Proviso, named after the Texas growers who strongly fought for it. The amendment stipulated that "for the purposes of this section, employment (including the usual and normal practices incident to employment), shall not be deemed to constitute harboring" (Calavita, 1992:68). The clear intention of the Texas Proviso was to protect "unaware" employers from being prosecuted in terms of the Kilgore amendment. The key issue was whether the "knowing employment" would be interpreted as harboring or not. Finally, the proviso was interpreted as follows:

The committee proposes a specific exemption for employment. It specifically provides that employment shall not constitute harboring. In other words, under the Committee proposal it is not illegal for ail employer knowingly and willfully to hire a wetback who has illegally entered the United States (Calavita, 1992:69. Emphasis added).

Despite such a loophole, or perhaps because of it, the amendment was approved by a margin of 69 to 12 , and President Truman and several Congressmen argued that had the amendment not passed, it could have held up negotiations with Mexico, for the bracero program was about to expire in several days, and the Korean war situation demanded a renewal of the program. However, Mexico continued to negotiate, even though its demand for employer sanctions were not satisfied. Furthermore, Mexican officials had asked their U.S. counterparts to have secret negotiations because of increasing opposition in Mexico to the bracero program. The Catholic Church, the Mexican Workers Federation (СTM), and opposition parties, among other groups, strongly criticized the government for exposing Mexicans to exploitation by the United States government. In the end, the Mexican government clearly acknowledged the benefits of the out-stream of Mexican workers, although it had to cope with the political implications of internal discontent, on the grounds of nationalist sentiments against the U.S. ${ }^{12}$

\footnotetext{
12 Little attention has been given to the internal political situation in Mexico, and how it
} affected Mexico's bargaining position vis a vis the United States. The study of the Mexican 
The U.S. government's expectation that contract-workers would return to Mexico when no longer needed conflicted with growers' needs. Although undocumented immigration took place regardless of restrictive policies, the bracero programs in the 1940's fostered even larger inflows of undocumented workers, despite the numbers of Mexicans deported during Operation Wetback. Labor demands outweighed the implementation of immigration policy, and the instrument envisaged as a control over undocumented workers by means of the implementation of employer economic sanctions, was proven ineffective.

Beginning with the enactment of the McCarran-Walter Act of 1952, the issue of employer sanctions as a strategy to halt immigration flows by reducing the benefits of hiring undocumented aliens, permeated political debate. Although attempts to introduce federal legislation providing economic sanctions against employers had failed in 1952, further attempts regained momentum in the late 1960 's after a series of Congressional Hearings came to the conclusion that the presence of undocumented migrants was not confined to agriculture. In 1972 and 1973 the House of Representatives passed legislation forbidding employment of illegal aliens, but those initiatives were blocked by the Chairman of the Agricultural Committee, Louisiana Democratic Senator James Eastland, on the grounds that agricultural employers feared the measures would make farm labor costlier, and because the proposed legislation failed to provide employers with guaranteed seasonal labor (Midgley, 1983: 71-92). ${ }^{13}$ Several initiatives that focused on economic sanctions against employers as a way to curb illegal immigration were enacted at state level in the early 1970's. Federal and state government officials called attention to the issue, demanding that illegal immigration stop. They alleged undocumented migrants displaced legal workers, depressed wages, increased the unemployment rate, and became a burden to the U.S. taxpayers as a result of aliens' used welfare and other public benefits. In an environment permeated by the public opinion that controlling immigration was a valid strategy to diminish economic hardships, states undertook legal initiatives in that direction.

In 1971, California Governor Ronald Reagan signed the Arnett Bill (Assembly Bill 528), which made it illegal to knowingly employ undocumented workers. Specifically, Section 2805.a. of the Labor Code

government's relationship with internal groups regarding the bracero issue has also been neglected. One such study is elaborated by Stephen P. Mumme, "Mexican Politics and the Prospects for Emigration Policy: A Policy Perspective", (1978:67-95).

${ }^{13}$ For a detailed account of legislation on employers sanctions blocked in the congress, see Kitty Calavita's Inside the State. The Bracero Program, Immigration, and the INS. (1992). 
read: "No employer shall knowingly employ an alien who is not entitled to lawful residence in the United States if such employment would have an adverse effect on lawful resident workers" (Calavita, 1983:3).

However, the original version of the bill, as introduced to the assembly, had to be amended several times before its enactment. One of the original provisions indicated that employers should verify prospective employees' legal eligibility for employment by requiring documents other than the social security card. The provision was defeated because legislators did not want to engage in a process to "harass" employers, and also because employers argued strongly that "it should not be the burden of the farmer to make an extensive investigation in regard with the background of persons who seek employment" (Calavita, 1983:4).

Once California enacted its employers' sanctions in 1971, eleven states and one city followed suit: Connecticut, Delaware, Florida, Kansas, Maine, Massachusetts, Montana, New Hampshire, New Jersey, Vermont, Virginia, and the city of Las Vegas introduced their own legislations. Nevertheless, a study conducted by Schwarz on the impact of employer sanctions in these states, found that sanctions were ineffective in deterring employers from hiring undocumented workers, for a wide variety of reasons. In eight jurisdictions, enforcement officials prosecuted very few cases and secured fewer convictions; by 1983 California had not convicted anyone under its law.

Enforcement of employers' sanctions has been given low priority because the federal government has failed to "signal" its support of enforcement, and because of judicial unwillingness to leave the responsibility for enforcing federal immigration policy to the states. Moreover, many court decisions regarding apprehension of suspected undocumented aliens affected the INS enforcement procedures, in which INS agents in the field were repeatedly found guilty of violating individuals' rights (Schawarz, 1983:371-407). For instance, in Almeida-Sanchez v. United States the Supreme Court ruled that some searches by roving INS patrols were unconstitutional, because INS officers had stopped suspected illegal aliens at a point only twenty-five miles from the U.S.-Mexico border. (INS officers were empowered to search within twenty-five miles from the border without violating the Fourth and Fourteenth amendments). However, because the road where suspects were stopped for questioning never crossed the border, the Supreme Court upheld that it could not be considered as the functional equivalent of a border. In United States v. Brignoni-Ponce and Illinois Councilv. Pilliod respectively, a roving patrol had stopped a vehicle for questioning based only on the grounds that occupants appeared to be of Mexican ancestry. 
The Court held that a seizure based on appearance of Mexican ancestry alone did not meet the requirements of "reasonable suspicion" to justify a stop, and it was thus unsconstitutional (Bañuelos, 1983:410-411).

\section{CONCLUSIONS}

Several issues worthy of comparing among the cases described. First, the economic demand for foreign workers on a large scale, and an expedient contracting process required by employers, undermined the governmental apparatus set out in the three receiving countries as the mechanism to control inflow of legal foreign workers. In addition, pressure stemming from large numbers of prospective contract workers, who expected a rapid contracting process in order to work abroad, generated migration flows outside the institutional mechanisms established by participating governments. A difference in the case of the United States was that immigration authorities became directly and explicitly involved in enhancing undocumented immigration as a means to respond to employers' demands for foreign labor. A similar pattern appears to have taken place in France, Germany, and the United States.

Second, unlike the United States, both France and Germany implemented a system of internal control of immigrants -or national identification systems - that aimed at strict control of foreign workers by means of residency and labor permits attached to specific firms and/or particular cities. The strategy of instituting a similar identification system in the United States has been strongly debated, but not implemented. The main obstacle in the United States is that such a system, would threaten individual liberties and privacy; the challenge is to find an accurate identification system while protecting the rights of the population at large, preventing the government from invading individuals' rights.

Third, whereas one of the main strategies for controlling illegal immigration in the United States has been border interdiction, in France and Germany this alternative was viewed as an option only since the early 1980 's. However, efforts to reduce illegal immigration by means of border interdiction have not stopped the inflows of illegal immigrants in any of these three countries.

Fourth, in all three countries, legal provisions seem to operate in favor of those who violate the law: employers and illegal immigrants. In Germany, the law implies that enforcement will be pursued only when illegal immigration has a negative effect upon the labor market; the law does not define criteria upon which to determine the impact of illegal workers on the labor market. In the United States, the McCarran-Walter 
Act of 1952 explicitly and intentionally allowed employers to hire undocumented workers, and released employers from any obligation to determine the legal status of their employees. In contrast, both France and Germany made employers responsible for determining the legal eligibility of their employees. Nevertheless, none of provisions apparently has prevented employers from hirig undocumented workers. In the three countries, different legal strategies that aim at the common goal of controlling illegal immigration often seem to operate with the opposite effect, or at least, such policies have not had their intended effects.

Fifth, a significant difference among these nations is the means by which immigration policy is made. In France, prior to the 1980's when immigration became a political issue, the National Assembly had limited control over immigration policy. Hammar argues that given the changing circumstances in the economy and the need for foreign workers during the 1960's, the nation needed a flexible way of dealing with immigration (Hammar, 1985:284). Until the 1980's the Executive branch had the ability to make decisions on immigration according to economic, social, and political factors.

In Germany, immigration policies have been the responsibility of federal authorities, private organizations, and local communities, in a more complex process of policy-making. Conflicting interests between the government, employers, local authorities, and communities that deal with foreign workers have made it difficult to reach agreements on how control illegal immigration. By the mid-1970's, the Bundestag was not consulted on issues related to immigration policies.

As for the United States, immigration policies are not decisions taken by the executive branch, or by a specific governmental agency. The complex process of deliberation and consultation with interest groups, and with the Executive, and the Legislative branch of the government makes policy-making more difficult. Perhaps the complicated decision-making process in the U.S. may explain why policies and strategies regarding illegal immigration were adopted earlier in other nations than in the U.S.

Finally, attempts to curb illegal immigration by imposing economic sanctions on employers who hired unauthorized workers could not be effectively enforced, due to legal loopholes that made it possible for employers to circumvent the law, and to employ foreign illegal workers almost at will. In the United States, federal legislation was finally introduced and enacted: the Immigration Reform and Control Act of 1986. This legislation in large part included the same kind of regulations implemented in both France and former West Germany, and is very similar to initiatives introduced by several states in the U.S. during the early 1970's. A convergence in immigration policy appears to be taking place in western, industrialized nations. 


\section{REFERENCES}

BAÑUELOS, Elsa. 1983. "Justice and the Undocumented Immigrants: Authority and Practices fo the Immigration and Naturalization Service", Stanford Journal of International Law, 19(2), Summer.

CALAVITA, Kitty. 1983. California's "Employers Sanctions": The Case of the Disappearing Law. University of California, San Diego, La Jolla.

- 1992. Inside the State. The Bracero Program, Immigration, and the INS, Routledge, Chapman and Hall, London.

CARDOSO, Lawrence A. 1980. Mexican Emigration to the United States, 1897-1931: Socio-Economic Patterns, The University of Arizona Press, Tucson.

CASTLES, Stephen. 1986. "The Guest-worker in Europe. An Obituary", International Migration Review, 20 (4), winter.

COATSWORTH, John. 1974. "Railroad, Landholding, and Agrarian Protest in the Early Porfiriato", The Hispanic American Historical Review, 54 (1), February.

CRAIG, Richard B. 1971. The Bracero Program. Interest Groups and Foreign Policy, University of Texas Press, Austin.

DE VOS, Jan. 1974. "Una legislación de graves consecuencias: acaparamiento de tierras baldías en México, con pretexto de la colonización, 1821-1910", Historia mexicana, 34 (113), July-September.

DRISCOLL, Bárbara A. 1985. El programa de Braceros ferroviarios, CEFNOMEX, Tijuana, B.C. México.

ESSER, Hermet and Herman Korte. 1985. "Federal Republic of Germany", in Tomas Hammar (ed.), European Immigration Policy. A Comparative Study, Cambridge University Press, Cambridge.

FERNANDEZ, Raul. 1977. The United States-Mexico Border: A Politic-Economic Profile, University of Notre Dame Press, Notre Dame.

GALARZA, Emesto. 1964. Merchants of Labor: The Mexican Bracero Story, McNally and Loftin, Charlotte.

GAMBOA, Eramo, 1990. Mexican Labor and World War II: Braceros in the Pacific Northwest, 1942-1945, University of Texas Press, Austin.

GARCIA Y GRIEGO. 1983a. Importation of Mexican Contract Labores to the United States, 1942-1964: Antecedents, Operation and Legacy, Program in United States-Mexico Studies, University of Califórnia, San Diego, La Jolla. 
- 1983b. "The Importation of Mexican Contract Labores? to the United States, 1942-1964. Antecedents, Operation, and Legacy", in Peter G. Brown and Henry Shue (ed.). The Border that Joins. Mexican Migrants and U.S. Responsibility?, Rowman and Littlefield, New Jersey.

- 1992. "Policymaking at the Apex: Intemational Migration, State Autonomy, and Societal Constraints", in Jorge A. Bustamante, Clark w. Reynolds, and Raul A. Hinojosa Ojeda (eds.), U.S.-Mexico Relations. Labor Market Interdependence, Stanford University Press, Stanford.

GURAK, Douglas T. and Fe Caces. 1992. "Migration Networks and the Shaping of Migration Systems", in Mary M. Kritz, Lin Lean Lim, and Hania Zlotnik (ed.), International Migration Systems. A Global Approach, Clarendon Press, New York.

HAMMAR, Tomas (ed.). 1985. European Immigration Policy. A Comparative Study, Cambridge University Press, Cambridge.

HANDLIN, Oscar. 1990. "The Nineteenth Century Immigration", in Robert W. Tucker, Charles B. Keely, and Linda Wringley (eds.), Immigration and U.S. Foreign Policy, Westview Press, Boulder. HOLLIFIELD, James F, 1992. Immigrants, Markets and States. The Political Economy of Postwar Europe, Harvard University Press, Cambridge.

HUTCHINSON, E.P. 1981. Legislative History of American Immigration Policy, 1798-1965, University of Pennsylvania, Philadelphia.

KEELY, Charles B. 1990. "Immigration in the Interwar Period", in Robert W. Tucker, Charles B. Keely, and Linda Wringley (eds.), Immigration and U.S. Foreign Policy, Westview Press, Boulder.

KUBAT, Daniel (ed.). 1983. The Politics of Return: International Return Migration in Europe, Center for Migration Studies, New York.

LEBON, André. 1983. "Retum Migration from France: Policies and Data", in Daniel Kubat (ed.), The Politics of Return: International Return Migration in Europe, New York, Center for Migration Studies.

MASSEY, Douglas S. Rafael Alarcon, Jorge Durand, and Humberto Gonzalez. 1987. Return to Aztlan. The Social Process of International Migration from Western Mexico. University of Califomia Press, Berkeley.

MEHRLANDER, Ursula. 1983. "Federal Republic of Germany", in Daniel Kubat (ed.), The Politics of Return: International Return Migration in Europe, Center for Migration Studies, New York. 
MESSINA, Antony M. 1990. "Political Impediments to the Resumption of Labour Migration to Western Europe", West European Politics, 13(1), January.

MIDGLEY, Elizabeth. 1983. "Immigrants and the Labor Market: Historical Perspectives and Current Issues", in Demetrios G. Papademetrius and Mark J. Miller (eds.), The Unavoidable Issue: U.S. Immigration Policy in the 1980's, Institute for the Study of Human Issues, Philadelphia.

MIL.LER, Mark J. and Philip Martin. 1982. Administering Foreign Worker Programs, Lexington, Lexington Books.

MORALES, Patricia. 1982. Indocumentados mexicanos, Grijalbo, México.

MOULIER, Yann and George Tapinos. 1979, "France", in Daniel Kubat (ed.), The Politics of Migration Policies. The First World in the 1970 's, New York, Center for Migration Studies.

MUMME, Stephen P. 1978. "Mexican Politics and the Prospects for Emigration Policy: A Policy Perspective", Inter American Affairs, 32(1), Summer.

U.S. General Accounting Office. 1985. Ilegal Aliens. Information on Selected Countries' Employment Prohibition Laws, Government Printing Office, Washington, D.C., October.

SCHAWARZ, Carl E. 1983. "Employer Sanction Laws, Worker Identification Systems, and Undocumented Aliens: The State Experience and the Federal Proposals", Stanford Journal of International Law, 19 (2), Summer.

VERBUNT, Gilles. 1985. "France", in Tomas Hammar (ed.), European Immigration Policy. A Comparative Study, Cambridge, Cambridge University Press.

WILPERT, Czarina. 1992. "The Use of Social Network in Turkish Migration to Germany", in Mary M. Kritz, Lin Lean Lim, and Hania Zlotnik (ed.), International Migration Systems. A Global Approach, Clarendon Press, New York. 